\title{
NEWS OF THE PROFESSION
}

\section{SECOND CONFERENCE OF POLISH AND AMERICAN HISTORIANS}

The Bicentennial Conference of Polish and American Historians, a collaborative scholarly event, sponsored by the Committee of Historical Sciences of the Polish Academy of Sciences, the Institute of History of the University of Warsaw, and the Department of History of the University of Iowa in cooperation with other universities, took place in Iowa City, Iowa, September 29-October 1, 1976. The conference was devoted to the problem "The American and European Revolutions, 1776-1840s: Socio-Political and Ideological Ramifications." Professor Stefan Kieniewicz (chairman of the Committee of Historical Sciences, Polish Academy of Sciences) and Professor Jaroslaw Pelenski (University of Iowa) served as the coordinators of this bicentennial event.

This historical conference was the second of its kind. The First Conference of Polish and American Historians took place in Nieborów, Poland, in May of 1974, and was the first such endeavor in the history of exchanges between Polish and American historians. The Second Conference of Polish and American Historians was the only bicentennial event of its kind which involved a group of scholars from an East European country.

The following scholars from various Polish and American academic institutions presented papers at the conference: Jan Bialostocki (University of Warsaw), Stefan Kieniewicz (Polish Academy of Sciences), Jerzy Skowronek (University of Warsaw), Jerzy Topolski (University of Poznań), Andrzej Walicki (Polish Academy of Sciences), Bogusław Leśnodorski (University of Warsaw) (submitted his paper), Anna M. Cienciala (University of Kansas), Istvan Deak (Columbia University), Kamil Dziewanowski (Boston University), Robert Forster (Johns Hopkins University), Sydney V. James (University of Iowa), Linda K. Kerber (University of Iowa), Jaroslaw Pelenski (University of Iowa), Stow Persons (University of Iowa), Alan B. Spitzer (University of Iowa), and Piotr S. Wandycz (Yale University).

Several institutions were instrumental in making this collaborative project possible: the Polish Academy of Sciences, the University of Warsaw, the University of Iowa, the National Endowment for the Humanities, and the International Research and Exchanges Board. The last two agencies were especially helpful in providing generous financial support. Following the conference, the Polish scholars also had the opportunity to be guests of a bicentennial program in Washington, D.C., sponsored by the State Department.

The proceedings of the two conferences of Polish and American historians will be published by the University of Warsaw and the Polish Academy of Sciences as special and separate volumes in the near future. Undoubtedly, these publications will be of concrete and lasting value both for scholarship and for future Polish-American cultural relations. One can only express hope that the Polish-American historical conference will be put on a permanent basis.

Jaroslaw Pelenski University of Iowa 